Original research article

\title{
Requirements for teachers in the context of postgraduate nursing education: Polish experiences
}

\author{
Dorota Ozga ${ }^{1 *}$, Wioletta Mędrzycka-Dąbrowska ${ }^{2}$, Aleksandra Gutysz-Wojnicka ${ }^{3}$, Asta Heikkilä ${ }^{4}$, \\ Leena Salminen ${ }^{4}$ \\ ${ }^{1}$ University of Rzeszow, College of Medical Sciences, Institute of Health Sciences, Rzeszow, Poland \\ ${ }^{2}$ Medical University in Gdansk, Department of Anaesthesiology Nursing and Intensive Care, Gdansk, Poland \\ ${ }^{3}$ University of Warmia and Mazury in Olsztyn, Collegium Medicum, School of Public Health, Olsztyn, Poland \\ ${ }^{4}$ University of Turku, Department of Nursing Science, Turku, Finland
}

\begin{abstract}
The competency of nurse teachers and collaboration between nurse educators, nurse leaders and mentors are crucial for achieving highquality Evidence-Based nursing education. The profession of a nurse teacher is one of public trust and it requires the integration of skills, attitudes, standards, and theoretical knowledge as well as awareness of individual, organisational and social circumstances. The data were collected via email using a structured questionnaire (A Tool for the Evaluation of Requirements of a Nurse Teacher). The respondents' evaluation of the professional competencies and the overall rating correlated with their age. Older age corresponded to higher scores in professional and teaching competencies, in personality factors, and to a higher general ERNT score $(p=0.019)$. The lowest scores were awarded for teaching competencies - which shows that postgraduate education should be more closely monitored in this respect. The tool for the Evaluation of Requirements of a Nurse Teacher (ERNT) designed for the needs of nurse education can also be implemented in the evaluation of postgraduate education of nurses and midwives.
\end{abstract}

Keywords: Polish version of ERNT; Postgraduate nursing education; Psychometric properties

\section{Introduction}

Worldwide, there is a wide range of systems and forms of postgraduate education of nurses available, and many new trends can be observed in this area (Rautiainen and Vallimies-Patomäki, 2016; Wangensteen et al., 2018). Furthermore, expectations with regard to support for the advancement of nursing competencies are increasing, not only due to demographic challenges such as population ageing, but also because of medical and nursing labour shortages (Wangensteen et al., 2018). Nurse educators play a key role in the advancement of nursing careers at all stages of education and are seen as experts in this field (Pennbrant, 2016). The competence of nurse educators is necessary for the implementation of Evidence-Based nursing education (Heikkilä et al., 2018; Salminen et al., 2013). Furthermore, nurse educators are responsible for improving pedagogical work methods in order to achieve learning objectives defined in specific countries, and to implement these in practice at a national and local level both in graduate programmes and in postgraduate training. Continuous transformations affecting society and the profession lead to inevitable changes in nursing education, which take into account the needs of nurse educators as well as competence-related requirements (Salminen et al., 2010; WHO, 2016).

\section{Background}

Participation in postgraduate education is considered to be every nurse's duty. It is pursued in order to develop the competencies necessary to provide high-quality nursing care in a more independent and confident way (Baxter and Edvardsson, 2018; Ng et al., 2016). There is abundant evidence for the various gains resulting from nurses' involvement in postgraduate education: it facilitates critical thinking, clinical reasoning and advanced nursing skills, it contributes to patient satisfaction and health outcomes, helps to avoid medical errors, and fosters the professional development of nurses and their sense of fulfilment (Aiken et al., 2003; Doughty et al., 2018; Kinsella et al., 2018; McKillop et al., 2016; Ng et al., 2016). Acquisition of advanced nursing competencies in a postgraduate education course is more effective if implemented in both theoretical and practical training settings, and if a goal-oriented supervision of trainees is assigned a major role in the student's overall professional development (Pitkänen et al., 2018). A substantial part of postgraduate education in many nursing specialties takes place within the clinical environment, which takes the form of practical training (Gardner et al., 2016; Nyhagen and Strøm, 2016; Ślusarska et al., 2018). However, there is little research focusing on the teaching-learning process, or on supervision and mentoring patterns in the context of postgraduate education (Gardner et al., 2016; Nyhagen and Strøm, 2016). On the

\footnotetext{
* Corresponding author: Dorota Ozga, University of Rzeszow, College of Medical Sciences, Institute of Health Sciences, St. Warzywna 1A, 35-310 Rzeszow, Poland; e-mail: gdozga@poczta.fm http://doi.org/10.32725/kont.2020.035 
other hand, competencies of nurse educators have been described in several ways. For example, in their review Zlatanovic et al. (2017) describe five competence categories for nurse educators: Academic competencies, Nursing competencies, Attitudes, Pedagogical competencies, and Management and digital technology. Meanwhile Mikkonen et al. (2018) describe three categories: Knowledge, Skills, and Attitudes and Values (WHO, 2016).

In Poland, nurses can participate in four types of postgraduate education, defined by the state, that are the same for individuals holding Bachelor's and Master's degrees (The Act on the profession of nurse and midwife, 2011; Ślusarska et al., 2018); these include specialist training in nursing (2 years), qualifying courses ( 6 months), specialised courses (at least 4 weeks) and additional training courses (short duration training programs). Each of these provides nurses with a different range of clinical competencies and gives them independence in their work with patients (Ordinance of the Minister of Health no. $497,2017)$. The majority of the training hours are delivered in clinical settings, e.g. practical training, at specialised centres, overseen by experienced supervisors and teachers, and intended to facilitate the acquisition of specialist expertise and advanced nursing skills in an array of nursing disciplines (Centre of Postgraduate Education of Nurses and Midwives, 2017a, b).

\section{Materials and methods}

The aim of this study is to assess the competence of nurse educators in the context of postgraduate education, using the Polish version of the tool for the Evaluation of the Requirements of a Nurse Teacher (ERNT).

\section{Design}

A cross-sectional research design was used.

\section{Participants and setting}

A convenience sample of nurses taking part in postgraduate training in a region of southern Poland was invited to take part in the study. 269 participants of a specialised course on cardiopulmonary resuscitation for nurses and midwives were invited to take part in the survey. The questionnaires were distributed during the final high fidelity simulation class of the 2017/18 academic year.

\section{Research instrument}

The competencies of nurse educators were measured using a tool for the Evaluation of Requirements of a Nurse Teacher (ERNT) (Salminen, 2000, Salminen et al., 2009). The ERNT is based on the original tool by Mogan and Knox (1987), but it was developed taking into account the relevant literature as well as the educational reforms and learning theories (Salminen, 2000; Salminen et al., 2013). The ERNT-tool consists of 20 items divided into five competency categories, each comprising four items: Nursing competence, Pedagogical competence, Evaluation skills, and Personality factors and relationship with students (Salminen, 2000; Salminen et al., 2013). The ERNT is scored on a Likert scale (ranging from 1 = totally disagree, to 5 = very much agree). The wording of the ERNT was modified depending on the respondent. Furthermore, the questionnaire covered issues related to associations between nurse educators and background factors. In this questionnaire the term 'nurse teacher' in a given teaching module refers to academic teachers (working at institutions of higher education, regardless of the form of employment) who are respon- sible for the implementation of practical education (practical classes / occupational placement) in the respective areas of clinical education (e.g. surgical, paediatric nursing, emergency department, physiotherapy department, etc.).

\section{Development of the Polish version of ERNT}

After obtaining consent from the author of the tool, the procedure of translating the original version of ERNT began. The original version was translated by two independent translators - on the basis of which the preliminary version of the tool was achieved. This was followed by a process of back-translation from Polish to English language by two practising experts in nursing who were fluent in English. During the preparation of the Polish version of the ERNT scale, an identical graphic form of the questionnaire and the same sampling criteria were used. In accordance with the objectives adopted by the authors of the current research project, more general terminology was used in the Polish version so that the tool could be applied to evaluate competencies of nurse educators working both in graduate and postgraduate educational programmes. As a result of this, a decision was made to add another reference name to the general scale, i.e. "nursing/professional competencies" in order to be able to apply the tool more broadly. Ultimately, the final version of the Polish ERNT instrument was approved (see Appendix).

\section{Statistical analysis}

In order to determine the internal structure of the questionnaire, an exploratory factor analysis was performed. The statistical significance level was set at $\leq 0.05$. The analyses were carried out with the IBM SPSS Statistics Suite v. 25. The results were examined with Pearson's correlation and Kruskal-Wallis tests, and are presented using descriptive statistics. For the purpose of identifying the required sample size, the n:p rule of thumb was applied; the $n: p$ is the minimum recommended ratio of sample size $(n)$ to the number of variables analysed $(p)$. The recommended $\mathrm{n}: \mathrm{p}$ ratio is at least 10 . In the present study, in which $n=269$ and $p=20$, it amounted to 13.30, thus the final sample size was within the recommended value.

\section{Ethical considerations}

The respondents were invited to participate in the study on a voluntary basis. Each of them was informed of the aim of the study and the research protocol. The participants were assured that the data collected during the study was anonymous and confidential. Furthermore, they were also informed of their right to withdraw at any time. It was assumed that informed consent for participation in the study was automatically granted by the respondents who returned completed surveys (by dropping them in a specially designated box). The research protocol, together with the respondent's consent form, were approved by the Ethics Committee at the University of Rzeszow (Resolution No. 5/9/2017). Permission to use the tool in the research project, and for cultural validation, was granted directly by the authors of ERNT.

\section{Results}

The study group consisted of 269 nurses from southern Poland - women $(98.9 \%, n=266)$ and men $(1.10 \%, n=3)$. The average age of the respondents was $37 \pm 10.43$ years. On average the participants had worked in intensive care units for $11.00 \pm 10.43$ years, and in the nurse/midwife profession for $12.50 \pm 10.80$ years (Table 1$)$. 
Table 1. Characteristics of the surveyed group of nurses

\begin{tabular}{lrr} 
Variables & \multicolumn{2}{c}{ [n=269] } \\
\hline & & $\%$ \\
\hline Gender & 266 & \\
$\quad$ Woman & 3 & 98.9 \\
$\quad$ Man & & 1.1 \\
\hline Education & 51 & \\
$\quad$ Secondary & 39 & 19.0 \\
$\quad$ Higher (Bachelor's) & 176 & 14.5 \\
$\quad$ Higher & 3 & 65.4 \\
$\quad$ No response & & 1.1 \\
\hline Practised profession & 38 & \\
$\quad$ Midwife & 227 & 14.1 \\
$\quad$ Nurse & 4 & 84.4 \\
$\quad$ No response & & 1.5 \\
\hline
\end{tabular}

\section{The competencies of nurse educators}

The overall score in the questionnaire assessing teachers' competences is the arithmetic mean of the number of points obtained for particular responses (ranging between 1 and 5). Within the respective subscale, the arithmetic mean of points was calculated (in the range between 1 and 5). The average result was $4.59(\mathrm{SD}=0.52 ; \mathrm{Me}=4.80)$. The scores in the subscales ranged from 4.52 (Pedagogical competence) to 4.71 (Relationships with students/interns) (Table 2).

No differences were shown in the competency level relative to the education level ( $p=0.431$ ) (Table 3 ).

The respondents' opinions concerning the nurse educators' competencies were examined in relation to the respondents' age. The findings showed that the latter factor indeed correlated with the evaluation of educators' professional competencies and the overall rating. The respondents' older age corresponded to more favourable opinions about the teachers' profession-

Table 2. Descriptive statistics for the respective scales and the general ERNT score

\begin{tabular}{lccccccc} 
Subscale & M & SD & Min & Max & Q1 & Me & Q3 \\
Nursing competence & 4.56 & 0.57 & 2.00 & 5.00 & 4.25 & 4.75 & 5.00 \\
Pedagogical competence & 4.52 & 0.60 & 2.00 & 5.00 & 4.25 & 4.75 & 5.00 \\
Evaluation abilities & 4.55 & 0.63 & 1.75 & 5.00 & 4.00 & 5.00 & 5.00 \\
Personality factors & 4.59 & 0.58 & 1.75 & 5.00 & 4.25 & 5.00 & 5.00 \\
Relationships with graduate/postgraduate students & 4.71 & 0.51 & 2.00 & 5.00 & 4.50 & 5.00 & 5.00 \\
Overall score & 4.59 & 0.52 & 2.30 & 5.00 & 4.35 & 4.80 & 5.00 \\
\hline
\end{tabular}

M, mean; SD, standard deviation; Min, minimum value; Max, maximum value; Q1, lower quartile; Me, median; Q3, upper quartile.

Table 3. The results of the ERNT questionnaire with a consideration of the education level of the respondents

\begin{tabular}{|c|c|c|c|c|c|c|c|c|c|c|c|}
\hline \multirow[t]{2}{*}{ Subscale } & \multicolumn{3}{|c|}{ Secondary } & \multicolumn{3}{|c|}{ Higher Bachelor's } & \multicolumn{3}{|c|}{ Higher Master's } & \multicolumn{2}{|c|}{ Statistics } \\
\hline & M & $\mathrm{Me}$ & SD & M & $\mathrm{Me}$ & SD & M & $\mathrm{Me}$ & SD & $\mathrm{H}$ & $p$ \\
\hline Nursing competence & 4.66 & 5.00 & 0.57 & 4.62 & 4.75 & 0.39 & 4.52 & 4.75 & 0.60 & 3.538 & 0.171 \\
\hline Pedagogical competence & 4.62 & 5.00 & 0.53 & 4.65 & 4.75 & 0.41 & 4.46 & 4.75 & 0.65 & 2.658 & 0.265 \\
\hline Evaluation abilities & 4.56 & 5.00 & 0.64 & 4.57 & 4.75 & 0.52 & 4.54 & 5.00 & 0.65 & 0.343 & 0.843 \\
\hline Personality factors & 4.68 & 5.00 & 0.56 & 4.60 & 4.75 & 0.42 & 4.56 & 5.00 & 0.62 & 2.224 & 0.329 \\
\hline Relationships with graduate/postgraduate students & 4.72 & 5.00 & 0.55 & 4.78 & 5.00 & 0.41 & 4.69 & 5.00 & 0.53 & 0.709 & 0.702 \\
\hline Overall score & 4.65 & 4.85 & 0.52 & 4.64 & 4.65 & 0.34 & 4.55 & 4.83 & 0.55 & 1.683 & 0.431 \\
\hline
\end{tabular}

M, mean; Me, median; SD, standard deviation; H, Kruskal-Wallis test.

Table 4. The correlation between age and ERNT scores

\begin{tabular}{lcc} 
Subscale & \multicolumn{2}{c}{ Age } \\
\cline { 2 - 3 } & $r$ & $p$ \\
\hline Nursing competence & $\mathbf{0 . 1 6 2}^{* *}$ & $\mathbf{0 . 0 0 8}$ \\
Pedagogical competence & $\mathbf{0 . 2 1 5}^{* *}$ & $\mathbf{0 . 0 0 0}$ \\
Evaluation abilities & 0.067 & 0.274 \\
Personality factors & $\mathbf{0 . 1 2 8}^{*}$ & $\mathbf{0 . 0 3 7}$ \\
Relationships with graduate/ & & \\
postgraduate students & 0.059 & 0.334 \\
Overall score & $\mathbf{0 . 1 4 3}^{*}$ & $\mathbf{0 . 0 1 9}$ \\
\hline$r^{\prime}$ Pearson's correlation; ${ }^{* *} p<0.01 ;{ }^{*} p<0.05$. \\
\hline
\end{tabular}

al and pedagogical competencies as well as personality factors, and to higher overall ERNT scores $(p=0.019)$. (Table 4).

In the analysis of the opinions concerning the competency level, the differences were found to reflect the respondents' seniority. Longer-lasting work experience in the given field and in the profession corresponds to a more favourable opinion of the teachers' professional and pedagogical competencies, and the relevant personality factors, and to a higher overall ERNT score $(p=0.012)$ (Table 5).

The analysis of the respondents' opinions about the nurse educators' competency level showed differences with regard to the profession practiced $(p=0.418)$ (Table 6). 
Table 5 . The correlation between job seniority and ERNT scores

\begin{tabular}{|c|c|c|c|c|}
\hline \multirow[t]{2}{*}{ Subscale } & \multicolumn{2}{|c|}{ Years worked in intensive therapy } & \multicolumn{2}{|c|}{ Years worked in the profession } \\
\hline & $r$ & $p$ & $r$ & $p$ \\
\hline Nursing competence & $0.173^{* *}$ & 0.005 & $0.174^{* *}$ & 0.004 \\
\hline Pedagogical competence & $0.193^{* *}$ & 0.002 & $0.218^{* *}$ & 0.000 \\
\hline Evaluation abilities & 0.083 & 0.182 & 0.077 & 0.209 \\
\hline Personality factors & 0.134* & 0.031 & $0.138^{*}$ & 0.025 \\
\hline Relationships with graduate/postgraduate students & 0.072 & 0.251 & 0.065 & 0.294 \\
\hline Overall score & $0.149^{*}$ & 0.017 & $0.153^{*}$ & 0.012 \\
\hline
\end{tabular}

Table 6. The correlation between the profession practised and ERNT scores

\begin{tabular}{|c|c|c|c|c|c|c|c|c|}
\hline \multirow[t]{2}{*}{ Subscale } & \multicolumn{3}{|c|}{ Midwife } & \multicolumn{3}{|c|}{ Nurse } & \multicolumn{2}{|c|}{ Statistics } \\
\hline & M & $\mathrm{Me}$ & $\mathrm{SD}$ & M & $\mathrm{Me}$ & SD & $\mathrm{H}$ & $p$ \\
\hline Nursing competence & 4.56 & 4.75 & 0.67 & 4.57 & 4.75 & 0.54 & -0.403 & 0.687 \\
\hline Pedagogical competence & 4.54 & 4.75 & 0.66 & 4.52 & 4.75 & 0.59 & -0.538 & 0.590 \\
\hline Evaluation abilities & 4.68 & 5.00 & 0.55 & 4.53 & 5.00 & 0.63 & -1.516 & 0.130 \\
\hline Personality factors & 4.68 & 5.00 & 0.53 & 4.58 & 5.00 & 0.58 & -1.243 & 0.214 \\
\hline Relationships with graduate/postgraduate students & 4.75 & 5.00 & 0.48 & 4.71 & 5.00 & 0.51 & -0.653 & 0.513 \\
\hline Overall score & 4.64 & 4.93 & 0.53 & 4.58 & 4.80 & 0.50 & -0.811 & 0.418 \\
\hline
\end{tabular}

\section{Discussion}

The teachers' competence varied in different competence areas - as has been reported in earlier studies (Salminen et al., 2013). Nurse educators must have an appropriate level of skills and competencies, which is especially important for post-graduate nursing education, as described in Appendix. Out of all the competency areas, the nurse educators received the lowest scores for their pedagogical competencies. Their nursing/professional competencies received higher scores. Nursing should only be based on the most recent achievements in the field when there is a close connection between scientific research, education and practice, and teachers of the profession apply the most recent knowledge gained during R\&D activities in educating all medical majors (Koivula et al., 2011; Salminen et al., 2013). When it comes to evaluation abilities, in this subscale the scores were higher. Fair and competent evaluation is crucial; according to many authors, students have the right to fair and honest assessment (Numminen et al., 2009; Oermann et al., 2009; Salminen et al., 2013).

In the case of personality factors, the results were even better. This permits the conclusion that for nurse educators specific personality traits are essential for the promotion of learning among students (Göncz, 2017; Ilic et al., 2016; Zamanzadeh et al., 2015). In this study the cooperation with nurse educators was evaluated as very good by the teachers themselves. Effective cooperation between nurse teachers and students leads to understanding, which encourages the integration of theory and practice; one of the key elements needed to ensure the appropriate competency level of nurse educators (Scully, 2011). Nurse teachers play a crucial role in educating responsible and skilful nurses at each level of education in all healthcare sectors. Based on the results of this study, it is possible to develop training for nurse educators and for other teachers of medical professions and further education in order to more effectively meet both the requirements resulting from the current labour demand and expectations of the public.

Education of healthcare professionals, including nurses, is constantly developing. The appropriate expertise of a nurse educator is of key importance for the advancement of knowledge, skills and attitudes of nurses. Ministries of health, regulatory bodies, healthcare professionals and communities (as the targets of educational outcomes) must be involved in and should support nursing education at all levels. High quality nurse education should take into account the updated and relevant knowledge, professional skills and positive attitudes and values. Only that way can we promote new approaches to education and curriculum planning, and develop nursing and other health care programmes. Moreover, this way we can implement the new knowledge and reform the curricula for nurses (WHO, 2016) as well as other medical professions such as midwives, paramedics, physicians and physiotherapists.

Ensuring high-quality competencies of teachers is a precondition for achieving high-quality education and for producing effective, efficient and well-qualified nurses, able to respond to the healthcare needs of the population to which they provide care. In postgraduate education this makes it possible to achieve the competencies required of advanced practise nurses. As claimed by Jim Campbell (Director, Health Workforce, World Health Organization, Executive Director, Global Health Workforce Alliance), competencies recognised as necessary in nursing education and practice are subject to change. Nursing personnel must practise, identify and accommodate new scientific evidence (Heikkilä et al., 2018) to culturally diversified populations and their changing needs. Education is the first and the most important precondition for change. The usefulness of the proposed competencies will be reflected 
by their effectiveness in bringing the required change. A lot of effort was put into defining a set of basic nurse educator competencies, which are classified in the following categories: Theories and Principles of Adult Learning, Curriculum and Implementation, Nursing Practice, Research and Evidence, Communication, Collaboration and Partnership, Ethical/Legal Principles and Professionalism, Monitoring and Evaluation, Management, Leadership and Advocacy (WHO, 2016). The main objective of these activities was to support teachers in achieving a higher proficiency level in teaching, in advancing essential knowledge and skills, and developing attitudes to effectively practise nursing in the 21st century.

The set of competencies defined for nurse educators can also be applicable to teachers of other medical professions. There is a lack of current research on the competency level of nurse teachers that takes into consideration WHO recommendations. Effective assessment of the competency level would enable a global discussion on this issue. This is crucial due to the fact that the guidelines intended for implementation in a given country are sometimes neglected, which is a huge threat to education in the 21 st century.

\section{Limitations}

The main limitation of this study results from the convenience sampling method applied. The nurses participating in the study were recruited in only one region of Poland and in one educational institution only, i.e. in a postgraduate education centre for nurses and midwives. Thus, the sample was too homogeneous to allow for more general conclusions. Further research should take into account a more diverse group of respondents. Moreover, the test-retest reliability of the tool (which is an important measure for its development) was not evaluated in the present study, and future research in this area is recommended.

\section{Conclusions}

The study provides new information related to the basic competency level of nurse teachers, from the viewpoint of nurses in postgraduate education. The results show that the educators' teaching competencies received the lowest scores. Therefore, organisations in charge of postgraduate education for nurses and midwives must perform more detailed monitoring of the qualification criteria defined for nurse teachers. The tool for Evaluation of the Requirements of a Nurse Teacher (ERNT) designed for the needs of nurse education can also be implemented in the evaluation of postgraduate education of nurses and midwives. Tools should be developed to enable multidimensional evaluation by training participants, organisers of educational activities, and teachers themselves.

\section{Conflict of interests}

The authors declare no potential conflict of interests with respect to the research, authorship, and/or publication of this article.

\section{Funding}

The author(s) received no financial support for the research, authorship, and/or publication of this article.

\title{
Požadavky na učitele v kontextu postgraduálního ošetřovatelského vzdělávání: polské zkušenosti
}

\begin{abstract}
Souhrn
Pro dosažení vysoce kvalitního ošetřovatelského vzdělání založeného na důkazech jsou kompetence vzdělavatelů zdravotních sester a spolupráce s vedoucími sester a mentory zásadní. Profese vzdělavatele zdravotních sester má důvěru veřejnosti a vyžaduje integraci dovedností, postojů, standardů a teoretických znalostí i povědomí o individuálních, organizačních a sociálních okolnostech. Data byla shromážděna pomocí strukturovaného dotazníku (Nástroj pro hodnocení požadavků zdravotní sestry), který byl rozeslán e-mailem. Hodnocení profesních kompetencí respondentů a celkové hodnocení odpovídalo jejich věku. Starší respondenti dosáhli vyššího skóre v profesních a pedagogických kompetencích, osobnostních faktorech a vyššího obecného skóre ERNT ( $p=0,019)$. Nejnižší skóre bylo uděleno za pedagogické kompetence - což ukazuje, že postgraduální vzdělávání by mělo být v tomto ohledu pečlivěji sledováno. Nástroj pro hodnocení požadavků vzdělavatele sester (ERNT) určený pro potřeby vzdělávání sester lze implementovat také do hodnocení postgraduálního vzdělávání sester a porodních asistentek.
\end{abstract}

Klíčová slova: polská verze ERNT; postgraduální vzdělávání sester; psychometrické vlastnosti

\section{References}

1. Act on professions of nurse and midwife (2011), with subsequent changes (in Polish). [online] [cit. 2020-08-31]. Available at: http://isap.sejm.gov.pl/isap.nsf/download.xsp/ WDU20111741039/U/D20111039Lj.pdf

2. Aiken LH, Clarke SP, Cheung RB, Sloane DM, Silber JH (2003). Educational levels of hospital nurses and surgical patient mortality. JAMA 290(12): 1617-1623. DOI: 10.1001/ jama.290.12.1617.

3. Baxter R, Edvardsson D (2018). Impact of a critical care postgraduate certificate course on nurses' self-reported competence and confidence: A quasi-experimental study. Nurse Educ Today 65: 156-161. DOI: 10.1016/j.nedt.2018.03.004.
4. Centre of Postgraduate Education of Nurses and Midwives (2017a). Training programme for the specialist training in anaesthesia and intensive care nursing. Warsaw (in Polish). [online] [cit. 2020-05-26]. Available at: http:// www.ckppip.edu.pl/uploads/docs/Programy_ksztalcenia/ Szkolenia\%20specjalizacyjne_1/Pi el\%C4\%99gniarstwo\%20 anestezjologiczne\%20i\%20intensywnej\%20opieki.pdf

5. Centre of Postgraduate Education of Nurses and Midwives (2017b). Training programme for the specialised course on cardiopulmonary resuscitation. Warsaw (in Polish). [online] [cit. 2020-04-27]. Available at: http://www.ckppip.edu.pl/ uploads/docs/Programy_ksztalcenia/kursy_specjalistyczne_3/ Resuscytacja\%20krazeniowo-oddechowa.pdf

6. Doughty L, McKillop A, Dixon R, Sinnema C (2018). Educating new graduate nurses in their first year of practice: The perspective and experiences of the new graduate nurses 
and the director of nursing. Nurse Educ Pract 30: 101-105. DOI: 10.1016/j.nepr.2018.03.006 .

7. Gardner A, Gardner G, Coyer F, Gosby H ( 2016). Educating for health service reform: clinical learning, governance and capability - a case study protocol. BMC Nurs 15: 32. DOI: 10.1186/s12912-016-0152-8.

8. Göncz L (2017). Teacher personality: a review of psychological research and guidelines for a more comprehensive theory in educational psychology. Open Review of Educational Research (4)1: 75-95. DOI: 10.1080/23265507.2017.1339572.

9. Heikkilä A, Hupli M, Katajisto J, Leino-Kilpi H (2018). Finnish graduating nursing students' research utilization competence. J Nurs Educ Pract 8(8): 119-127. DOI: 10.5430/jnep.v8n8p119.

10. Ilic D, Harding J, Allan C, Diug B (2016). What are the attributes of a good health educator? Int J Med Educ 7: 206-211. DOI: $10.5116 /$ ijme.5765.0b6a.

11. Kinsella D, Fry M, Zecchin A (2018). Motivational factors influencing nurses to undertake postgraduate hospital-based education. Nurse Educ Pract 31: 54-60. DOI: 10.1016/j. nepr.2018.04.011.

12. Koivula M, Tarkka MT, Simonen M, Katajisto J, Salminen L (2011). Research utilization among nursing teachers in Finland: a national survey. Nurs Educ Today 31(1): 24-30. DOI: 10.1016/j.nedt.2010.03.008.

13. McKillop A, Doughty L, Atherfold Ch, Shaw K (2016). Reaching their potential: Perceived impact of a collaborative academicclinical partnership programme for early career nurses in New Zealand. Nurs Educ Today 36: 145-151. DOI: 10.1016/j. nedt.2015.09.005.

14. Mikkonen K, Ojala T, Sjögren T, Piirainen A, Koskinen C, Koskinen M, et al. (2018). Competence areas of health science teachers - a systematic review of quantitative studies. Nurs Educ Today 70: 77-86. DOI: 10.1016/j.nedt.2018.08.017.

15. Mogan J, Knox JE (1987). Characteristics of 'best' and 'worst' clinical teachers as perceived by university nursing faculty and students. J Adv Nurs 12(3): 331-337. DOI: 10.1111/j.13652648.1987.tb01339.x.

16. Ng L, Eley R, Tuckett A (2016). Exploring factors affecting registered nurses' pursuit of postgraduate education in Australia. Nurs Health Sci 18(4): 435-441. DOI: 10.1111/ nhs.12289.

17. Numminen O, van der Arend A, Leino-Kilpi H (2009). Nurse educators' and nursing students' perspectives on teaching codes of ethics. Nurs Ethics 16(1): 69-82. DOI: $10.1177 / 0969733008097991$.

18. Nyhagen R, Strøm A (2016). Postgraduate students' perceptions of high-quality precepting in critical care nursing. Nurs Educ Pract 21: 16-22. DOI: 10.1016/j.nepr.2016.09.002.

19. Oermann MH, Yarbrough SS, Saewert KJ, Ard N, Charasika ME (2009). Clinical evaluation and grading practices in schools of nursing: national survey findings part II. Nurs Educ Perspect 30(6): 352-357.

20. Ordinance of the Minister of Health no. 497, on the type and scope of preventive, diagnostic, therapeutic and rehabilitation services provided by a nurse or a midwife independently without a doctor's order (2017) (in Polish). [online] [cit. 203108-31]. Available at: http://www.oipip.pila.pl/images/rozp._ MZ_497.pdf

21. Pennbrant S (2016). Determination of the Concepts "Profession" and "Role" in Relation to "Nurse Educator". Journal of Professional Nursing (32)6: 430-438. DOI: 10.1016/j. profnurs.2016.02.003.

22. Pitkänen S, Kääriäinen M, Oikarainen A, Tuomikoski AM, Elo S, Ruotsalainen H, et al. (2018). Healthcare students' evaluation of the clinical learning environment and supervision - a crosssectional study. Nurse Educ Today 62: 143-149. DOI: 10.1016/j. nedt.2018.01.005.

23. Rautiainen E, Vallimies-Patomäki M (2016). A review of the organization, regulation, and financing practices of postgraduate education in clinical nursing in 12 European countries. Nurse Educ Today 36: 96-104. DOI: 10.1016/j. nedt.2015.08.004.

24. Salminen L (2000). Hoitotyön opettajan muotokuva opettajaan kohdistuvat vaatimukset ja niiden arvionti [Portrait of a nurse teacher - requirements for teachers evaluated]. Doctoral dissertation. Annales Universitatis Turkuensis. Sarja Ser. C Osa - Tom. 158. Scripta Lingua Fennica Edita. Turku.

25. Salminen L, Melender HL, Leino-Kilpi H (2009). The competence of student nurse teachers. Int J Nurs Educ Scholars 6(1): 35. DOI: 10.2202/1548-923X.1803.

26. Salminen L, Minna S, Sanna K, Jouko K, Leino-Kilpi H (2013). The competence and the cooperation of nurse educators. Nurs Educ Today 33(11): 1376-1381. DOI: 10.1016/j. nedt.2012.09.008.

27. Salminen L, Stolt M, Saarikoski M, Suikkala A, Vaartio H, Leino-Kilpi H (2010). Future challenges for nursing education European perspective. Nurs Educ Today 30(3): 233-238. DOI: $10.1016 /$ j.nedt.2009.11.004.

28. Scully NJ (2011). The theory-practice gap and skill acquisition: an issue for nursing education. Collegian. 18(2): 93-98. DOI: 10.1016/j.colegn.2010.04.002.

29. Ślusarska B, Zarzycka D, Dobrowolska B, Marcinowicz L, Nowicki G (2018). Nursing education in Poland - The past and the new development perspectives. Nurs Educ Pract 31: 118-125. DOI: 10.1016/j.nepr.2018.05.010.

30. Wangensteen S, Finnbackk E, Adolfsson A, Kristjansdottir G, Roodbol P, Ward H, Fagerström E (2018). Postgraduate nurses' self-assessment of clinical competence and need for further training. A European cross-sectional survey. Nurs Educ Today 62: 101-106. DOI: 10.1016/j.nedt.2017.12.020.

31. WHO (2016). Nurse educator core competencies. [online] [cit. 2019-12-20]. Available at: https://www.who.int/hrh/nursing midwifery/nurse_educ_core_competencies/en/

32. Zamanzadeh V, Jasemi M, Valizadeh L, Keogh B, Taleghani F (2015). Effective factors in providing holistic care: a qualitative study. Indian J Palliat Care 21(2): 214-224. DOI: 10.4103/0973-1075.156506.

33. Zlatanovic T, Havnes A, Mausethagen S (2017). A Research Review of Nurse Teachers' Competencies. Vocations and Learning 10: 201-233. DOI: 10.1007/s12186-016-9169-0. 